Original Research Paper

\title{
Profitability and Financial Sustainability Analysis in Italian Aquaculture Firms by Application of Economic and Financial Margins
}

\author{
Mattia Iotti and Giuseppe Bonazzi \\ Department of Civil Engineering, Environment, Territory and Architecture (DICATeA), \\ University of Parma, Parma, Italy
}

\author{
Article history \\ Received: 31-01-2015 \\ Revised: 28-2-2015 \\ Accepted: 25-3-2015 \\ Corresponding Author: \\ Mattia Iotti \\ Department of Civil \\ Engineering, Environment, \\ Territory and Architecture \\ (DICATeA), University of \\ Parma, Parma, Italy \\ Email: mattia.iotti@unipr.it
}

\begin{abstract}
Agricultural Firms operating in the aquaculture sector in Italy are often characterized by high investment and high capital intensity. In fact, these companies need to develop structures and breeding systems to generate adequate cash flow to repay their investment in fixed assets. In addition, the biological cycle of breeding further extends the need for capital, in this case to finance working capital. There is therefore often a mismatch between the economic and financial cycles, wherein profit margins may differ from financial margins. In this way, such companies have an economic advantage but no sustainable financial cycle. In these cases, several crisis may force companies to default, especially when firns are unable to cover debt repayment. This difficulty is particularly present in Italy, where aquaculture firms are often Small and Medium Enterprises (SMEs) and therefore have greater difficulty than large companies accessing the capital market. Our research evaluates the cost effectiveness and financial sustainability of a sample of forty firms operating in the aquaculture sector in Italy, within a timespan of five years, through comparative analysis of the economic and financial margins. The analysis shows that such firms are capital intensive (TA/VP of median value is $1.16 \%)$. Financial debt emerges as the first source of capital then increasing companies' financial dependence through credit systems and borrowing costs. Firms have a particular absorption in the NWC cycle, with I_DAYS being 143.29 days, AR_DAYS being 72.75 and 145.51 AP_DAYS expressing financial operating cycle (I_DAYS + AR_DAYS - AP_DAYS) with a length of 70.53 days. Profit margins, even if they are correlated with financial margins, are lower on average. The research highlights that economic model worst explains FCFE $\left(\mathrm{F}=0.011\right.$ and adjusted $\left.\mathrm{R}^{2}=0.803\right)$, while the financial model best explains FCFE $\left(\mathrm{F}=0.000\right.$ and adjusted $\mathrm{R}^{2}=$ 0.922). Our research will be further developed through analyzing cooperatives, unincorporated partnerships and sole proprietorships. It may also be useful to undertake a comparative analysis of aquaculture firms operating in other countries of the Mediterranean basin.
\end{abstract}

Keywords: Financial Sustainability, Profitability, Aquaculture Firms, Free Cash Flow to Equity, Operating Cycle, Net Working Capital

\section{Introduction}

The world of aquaculture production has increased in recent decades and between 2003 and 2012, world production almost doubled from 32 to 63 million tons, with about $90 \%$ of production currently located in Asia. Aquaculture already accounts for nearly $40 \%$ of the global supply of fish for human consumption (FAO, 2012a; 2012b; 2013a; 2013b). In 2012, European Union (EU) production was 1.3 million tons, with annual sales of $€ 4$ billion; the major producing countries in Europe are France, the UK, Greece, Spain and Italy, which account for $77 \%$ of the value of sales of aquaculture in Europe. Italy, which produces $11 \%$ of the production, which amounts to $€ 423$ million, mainly produces clams and mussels (Mytilus galloprovincialis), worth $€ 146$ 
million; followed by trout (Oncorhynchus mykiss), worth $€ 140$ million; and sea bream (Sparus aurata) and sea bass (Dicentrarchus labrax), worth $€ 60$ million (Guillen and Motova, 2013).

In Italy, aquaculture has very ancient roots, even if control over the biological cycle of breeding animals is a relatively recent development. Today, the Italian productive structure is characterized by business systems that differ by management type, production cycle and geographic location. Above all, management of fisheries in coastal lagoons is an old and established tradition in Italy. The increase in production, which has characterized national aquaculture over the past fifty years, has been supported mainly by the development of production tanks, accompanied by a continuous update of traditional farming techniques. In Italy in 2013, 8,427 companies were active in the fishing sector, with 3,393 aquaculture firms, of which 1,426 were in the Veneto region and 1,138 in Emilia-Romagna. Aquaculture firms are localized mainly in Northern Italy, although there are important companies in the south, especially in Sicily, characterized by satisfactory economic performance (Santulli and Modica, 2009; Di Trapani et al., 2014). The structure of the sector has been affected by legal changes, however. As aquaculture takes the form of fish farming or cultivation, different from simple "capture" or "collection," it is therefore considered a form of agriculture regardless of whether it is implemented inland (fresh or brackish) or in marine waters (both onshore and offshore plants).

Article 1 of the Decree of May 18, n. 228, "Orientation and modernization of the agricultural sector," in fact redefines Article 2135 of the Civil Code, which defines aquaculture (freshwater, brackish, or marine) as an agricultural activity. Article 3 paragraph 3 of the Decree of May 27, 2005, n. 100, is also expected to equate aquaculture entrepreneurialism to agrarian entrepreneurialism. Even in the EU, aquaculture is qualified as an agricultural activity and is defined as all forms of aquaculture rearing or cultivation of aquatic organisms using techniques designed to increase, beyond the capacity of the natural environment, the yield of the organisms in question. These remain the property of a natural or legal person throughout the rearing and culture stage, including the collection, as per Article 3 letter $\mathrm{d}$ of Regulation (EC) No. 1198/2006 of July 27, 2006, on the European Fisheries Fund (OJ L 223, 15.8.2006).

The qualification of the companies as aquaculture farms poses some problems; in fact, in standard Italian law, farms are not subject to bankruptcy and it is therefore not possible to uniquely define the point at which a company defaults and proceed to an analysis of predictors of failure. For such an analysis, it would be necessary to approximate the default status using proxy variables, such as the status of voluntary liquidation.
Proxies pose the possible problem of not being clear indicators of default, as, for example, liquidation can occur even in the absence of crisis by the will of an entrepreneur who intends to cease trading.

Other methodological problems are caused by the presence of cooperatives in the aquaculture sector. Cooperatives, in fact, as several studies have shown (Bonazzi and Iotti, 2014a), have typical annual accounts that are difficult to compare with companies' capital ones. In cooperative firms, members are remunerated via rebates and this determines that operating income and net income can be unreliable indicators of profitability. Cooperative enterprises are thus not included in this analysis and further development of this research will be relevant to the analysis of cooperative firms operating in the aquaculture sector, applying specific indices ratios to analyze annual accounts in an effort to take into account the typicality of cooperative firms.

The analysis of annual accounts is the focus of this article. In fact, companies in the sector need to have high amounts of capital to finance investment in capital assets (property, plant and equipment) and working capital (including the value of fish during the breeding cycle). The International Accounting Standard (IAS) 41 requires that fish be classified as working capital during the breeding cycle. Since the change in inventories and sales not yet received, positively impacts the production value on company profit, there is frequently a misalignment between profit and cash flow in aquaculture firms, with situations in which companies, despite being profit positive, are not able to support payments during the financial cycle.

Again, large-scale distribution sales cause a delay in collection of receivables, with more negative effects on the financial sustainability of the business cycle. Moreover, processing firms suffer for frequently not having differentiable production levels, even with modest brand recognition in the consumer market. The low level of consumer loyalty then reduces the bargaining power of processing firms in the face of retail firms (Christensen et al., 2011; Macfadyen et al., 2012; El-Sayed et al., 2014). The typical characteristics of food production have been the subject of several studies in Italy, which revealed the strategies essential to ensuring the profitability of firms (Lanfranchi et al., 2014; Sgroi et al., 2014; Tudisca et al., 2014a; Carluccia et al., 2015) and performed analyses of the costs involved (Tudisca et al., 2013; Tudisca et al., 2014b; Iotti and Bonazzi, 2014a) even considering technical and economic analysis (Strano et al., 2014). These analyses have played an extensive role in the international development of the aquaculture sector (Copeland et al., 2005; Bozoglu and Ceyhan, 2009; Bedecarratz et al., 2011).

Since data on the capital needed to finance a business, known as equity capital or debts, is necessary 
to evaluate the performance of capital injected into that business, the same is also necessary to evaluate cash flow generated from operations to quantify whether such cash flow is sufficient to ensure the sustainability of the business cycle in terms of debt repayment. In aquaculture, this assessment is relevant for the time lag that exists between the business cycle and financial cycle, which can lead to strategically wrong decisions being made, with a resulting default risk for companies.

In this regard, it should be noted that there can be situations in which, even in the face of positive profits, firms in the sector have difficulty repaying their debts due to the absorption of capital in the working capital cycle. The joint application of the economic and financial approach for the assessment of affordability and sustainability management can also give significantly different results between the two approaches, as demonstrated for other sectors by several studies (Greenberg et al., 1986; Kwon, 1989; Dechow, 1994; Russell, 2009; Iotti and Bonazzi, 2014b; Sgroi et al., 2015). This situation occurs particularly in SMEs characterized by absorption of working capital (Glancey, 1998; Kieschnick et al., 2008).

In the aquaculture sector, companies use the following forms of funding in addition to venture capital: (1) For the financing of investments in property, plant and equipment as a Fixed Asset investment (FA), firms prefer bank loans to medium and long-term loans. The usual technique is to take out a mortgage with a mortgage guarantee and, less frequently, without a warranty, with a shorter amortization period, with collateral pledged (usually on securities), or with the guarantee of signature, often by the shareholders or a consortia credit guarantee; (2) for the financing of working capital, firms prefer lines of short-term financing, such as advances on trade receivables, advances on contracts and advances on the stock of breeding fish. For medium-term financing, businesses have a contractual commitment to pay, on the basis of an amortization schedule, the debt plus interest expense (socalled debt service), while in the case of short-term financing, businesses pay the cost of the debt and proceed to the payment of the principal of the loan obtained through the monetization of supply once trade receivables have been collected.

It is therefore important to assess the sustainability of debt services and the overall sustainability of the aquaculture business cycle. A general theme is that companies often use public funds granted to financial investments and also receive grants for operating expenses. These funds are provided in particular by the EU and in fact, one of the objectives of the Common Fisheries Policy (CFP) and its financing instrument, the European Fisheries Fund (EFF), until 2013, was to encourage the sustainable development of aquaculture. Therefore, up to May 2013, the EFF provided $€ 400$ million to finance productive investment, environmental measures and health in aquaculture. The EFF had five priorities and a total budget of $€ 4.3$ billion, of which the second priority for aquaculture, inland fishing and the processing and marketing of fishery products, was funded with $€ 1.2$ billion, of which $€ 438$ million was public funding for aquaculture, to fund 5,826 projects.

The objectives of this work are therefore (1) to conduct a comparison of economic performance and financial results among aquaculture enterprises in Italy and (2) to determine whether the economic results approximate properly the cash flow generating process and thus can be properly used for the quantification of coverage of debt services and sustainability of the management cycle. As companies in the sector are mostly SMEs, it is relevant to this research for us to identify the correct margins and/or streams and indexes. SMEs have, in fact, limited access to the equity capital market (stock market, venture capital, private equity, etc.) and to financial debt (bank debt, structured finance, syndicated loans, etc.), as shown by several studies (Grablowsky, 1976; Dunn and Cheatham, 1993; Peel and Wilson, 1996; Molina and Preeve, 2009; Woods et al., 2014) highlighting the need for analysis of economic feasibility and financial projects even in the case of aquaculture (Molinos-Senante et al., 2010; Kaiser et al., 2010; Naziri, 2011; Kim and Lipton, 2011; Shamshak, 2011; Hadelan et al., 2012; Kim et al., 2012; Vilela et al., 2013; Emdad Haque et al., 2015).

Evaluation indices of corporate sustainability with more precise calculation methods may then allow business owners to properly assess, in advance, the sustainability of the management cycle. Secondly, such indices would allow credit institutions to form a more correct creditworthiness process for firms. The analysis could also be useful for policymakers, who can intervene with aid policies directly (funding for operating expenses and capital) or indirectly (guaranteed consortia) in favor of companies for which such indices are correctly evaluated with the employment of public funds, thus limiting the risk of inefficient use of collective resources.

This analysis is particularly relevant considering the environmental role of aquaculture in terms of sustainable development (El-Gayar, 2003; De Ionno et al., 2006; Holmer, 2010; Bhattacharya et al., 2011; Ferreira et al., 2012; De Blasi et al., 2012; Shi et al., 2013). On this topic, accrual and cash flow measures have been applied to evaluate firms' performance times (Nasir et al., 2004). In the article, we apply this analysis to verify that the sample firms have significant differences between economic and financial margins. This could be particularly relevant for aquaculture firms, which are often capital intensive with a high need for financial debt to cover investments in fixed assets and working capital.

To achieve this goal, we have analyzed economic and financial margins in order to highlight correlations and statistically significant differences, even applying 
multiple regression models to quantify Free Cash Flow to Equity (FCFE) generation in aquaculture firms. In the aquaculture sector, the suggested assessment is relevant because of the time lag between the economic and financial cycles, which can lead to wrong strategic decisions and even increased risk of financial crisis. The results of this article could be applied to improve public aid and actions for private firms, including public lines of credit, after evaluating the financial sustainability of firms that would receive public funds, thus limiting inefficient use (Boschi et al., 2014).

\section{Materials and Methods}

\section{Balance Sheet Analysis Approach}

The annual account is the most important basic data for analysis of firms' management. This document is mandatory in Italy for corporations and cooperative societies. Italian law requires that the annual account be the main source of information to protect third parties who have business relations with companies characterized by limited liability of their members. The annual account is therefore the main informative document and to fulfill the duty of disclosure to third parties, the annual account is made up of a balance sheet, an income statement and integer notes, as is ruled by Article 2423 et sequent of the Italian Civil Code, as expressed by Legislative Decree no. 127/91, applying the fourth EU directive about company and annual accounts (EU Directive 78/660 / EEC IV of July 25, 1978).

The adoption of the annual account by companies enables the provision of a homogenous information base at the European level, drawn up on the basis of accounting principles. The homogenized accounting rules in Europe favor comparisons between the data of companies operating in different sectors and also between companies in the same sector. The annual accounts are prepared on an accrual basis that quantifies management results in terms of profit (Dechow et al., 1998; Dechow et al., 2012). These accrual principles are affected by the legal criteria of accounting, including the principle of the protection of third parties, called prudence, as required by Article 2423bis of the Civil Code.

The economic approach does not take into account the actual time of manifestation of monetary operations. This can be seen from several studies relating to companies with large investments in fixed assets (Fazzari and Petersen, 1993; Cleary, 1999; De Miguel and Pindado, 2001; Bagella et al., 2001; Caggese and Cunat, 2014) and working capital (Shin and Soenen, 1998; Howorth and Westhead, 2003; Padachi, 2006; Caggese, 2007; Taylor, 2011; Ukaegbu, 2014; Kroes and Manikas, 2014; Iotti and Bonazzi, 2014c). In this research, we apply the approach of annual account analysis developed for the agri-food sector with capitalintensive characteristics (Bonazzi et al., 2012).

In this approach, the balance sheet quantifies investments in assets in a given period ( $\mathrm{t}$ ) as the left side of Equation (1). These investments are financed with capital financing and form the balance sheet liabilities on the right side of Equation (1), as follows:

$$
\begin{aligned}
& F A_{t}+W C i_{t}^{a}+W C a r_{t}^{a}+W C o_{t}^{a}+L_{t}= \\
& =E_{t}^{s c}+E_{t}^{r}+\Pi_{t}^{p T}+W C a p_{t}^{s}+W C o_{t}^{s}+D F_{\mathrm{t}}^{M<12}+D F_{\mathrm{t}}^{M>12}
\end{aligned}
$$

In Equation (1), assets are composed by FA (fixed assets), $\mathrm{WCi}^{\mathrm{a}}$ (working capital assets: inventories), $\mathrm{WCar}^{\mathrm{a}}$ (working capital assets: Accounts receivable), $\mathrm{WCo}^{\mathrm{a}}$ (working capital assets: other assets) and $\mathrm{L}$ (liquidity). Sources of capital are represented by $\mathrm{E}^{\mathrm{sc}}$ (share capital), $\mathrm{E}^{\mathrm{r}}$ (reserves), $\Pi^{p T}$ (profit after taxes), $\mathrm{WCap}^{\mathrm{s}}$ (working capital debts: Accounts payable), $\mathrm{WCo}^{\mathrm{s}}$ (working capital debts: other debts), $D F^{M<12}$ (financial debts due within twelve months) and $D F^{M>12}$ (financial debts due after twelve months). The left side of Equation (1) for the given period $(t)$ represents the invested capital as Total Assets (TA) and the right side represents the total sources of capital as the sum of equity capital $(\mathrm{ET}=$ $\left.E^{s c}+E^{r}+\Pi^{p T}\right)$ and debt capital $\left(\mathrm{DT}=\mathrm{WCap}^{\mathrm{p}}+\mathrm{WCo}^{\mathrm{p}}+\right.$ $\left.D F^{M<12}+D F^{M>12}\right)$. The going concern must be ET $>0$, because a situation where ET $\leq 0$ expresses the failure of the company to annul the equity capital. If we were to highlight the role of the financial debt between the sources of funds, we could then express, for a given time $(t)$, Net Financial Position $\left(\mathrm{NFP}_{\mathrm{t}}\right)$ as follows:

$\left(D F_{\mathrm{t}}^{M<12}+D F_{\mathrm{t}}^{M>12}\right)-L_{t}=N F P_{t}$

In Equation (2) $\left(D F^{M<12}+D F^{M>12}\right)<L_{t}=>P F N_{t}<0$ expresses a financial surplus. Again, Net Working Capital investment $\left(\mathrm{NWC}_{\mathrm{t}}\right)$ expresses the absorption of financial resources through purchasing, transformation and selling (Hill et al., 2010; Baños-Caballero et al., 2014; Darun et al., 2015). NWC is given, in a time $(t)$, as follows:

$$
\begin{aligned}
& \left(W C i_{t}^{a}+W C a r_{t}^{a}+W C o_{t}^{a}\right)-\left(W C a p_{t}^{s}+W C o_{t}^{s}\right)= \\
& =W C_{t}^{a T}-W C_{t}^{s T}=N W C_{t}
\end{aligned}
$$

For the majority of companies (Dechow et al., 1998; Kroes and Manikas, 2014), the cycle of payments and receipts as a result of working capital, known as the operating cash cycle, is shorter than the cycle since the exit of money for investment and its return, called the investment cycle. In Equation (3), given a generic period $(t), W C^{a T}$ is working capital total assets and $W C^{S T}$ is working capital total sources. NWC quantifies the net resources generated $(\mathrm{NWC}<0)$ or absorbed $(\mathrm{NWCt}>0)$ 
by the working capital management cycle (Love et al., 2007; Baños-Caballero et al., 2013). It has been shown that the management of working capital is particularly relevant for small firms (Arcelus and Srinivasan, 1993; Saccurato, 1994; Chittenden et al., 2000; Kieschnick et al., 2013), as these enterprises have limited access to the capital market in the medium term and then tend to finance fixed asset investments with debt maturing within twelve months and show rates of default higher than those of large firms (Grablowsky, 1976; Dunn and Cheatham, 1993; Peel and Wilson, 1996; Gray et al., 2006; Molina and Preeve, 2009). This is true even in recent years in Italy (Modina and Pietrovito, 2014; Gordini, 2014). This has particular relevance for the aquaculture sector, where most companies are classified as SMEs. In these enterprises, an increase in the value of NWC determines the need for funding to be carried out with equity capital or debt capital. The expansion of the use of capital in NWC therefore involves an increase in the use of capital that must obtain remuneration and, in the case of debt capital, includes debt repayment.

\section{Income Statement Analysis Approach}

In the annual account, in a given period $(t)$, the income statement quantifies profit as the difference between revenues and costs, applying the economic approach, which differs from the financial approach in that the former is based on the creation of value, while the second is based on cash flow. The Value of Production (VP), in a given time $(t)$, is given by the following:

$$
\begin{aligned}
& \sum_{i=1}^{I} p_{t, i} q_{t, i}+\left(\sum_{f=1}^{F} W C i_{t, f} v_{t, f}-\sum_{g=1}^{G} W C i_{t-1, g} v_{t-1, g}\right)= \\
& =S_{t}+\left(W C i_{t}-W C i_{t-1}\right)=S_{t}+\Delta W C i_{t, t-1}=V P_{t}
\end{aligned}
$$

In Equation (4), $p_{t, i}$ is price per unit, at time $t$, of goods and services sold in number $I \geq 1 ; q_{t}$ is the quantity of goods and services sold (I); and $W C i_{t, f}$ and $W C i_{t-1, f}$ are the value of inventories, in number $F \geq 1$ and $G \geq 1$, at time $t$ and $t-1$, respectively. These assets are valued at their unit values $(v): S_{t}$ is sales at time $t$, while $\Delta W C i_{t, t-1}$ indicates the change in the value of inventories from time $t$ - 1 to time $t$. The production value is a stream value (Dechow and Dichev, 2002; Orpurt and Zang, 2009), that is, a value that is formed during a period, in this case the period $t$, regardless of the values assumed in moments $T \in(-\infty, t-1]$. The monetary operating costs for a generic time $(\mathrm{t})$ are as follows:

$$
\begin{aligned}
& M_{t}=\sum_{m=1}^{M} m_{t, m} q_{t, m} ; S_{t}=\sum_{s=1}^{S} s_{t, s} q_{t, s} ; R_{t}= \\
& =\sum_{r=1}^{R} r_{t, r} q_{t, r} ; \quad \mathrm{L}_{\mathrm{t}}=\sum_{l=1}^{L} l_{t, l} q_{t, l} ; O_{t}=\sum_{o=1}^{O} o_{t, o} q_{t, o}
\end{aligned}
$$

where, $M_{t}$ is costs for raw materials; costs of services are $S_{t}$; costs for use of third-party assets, such as rents and lease payments, are $R_{t}$; costs for employees are $L_{t}$; and other operating costs are $O_{t}$. In Equation (5), $m_{t, m}, s_{t, s}, r_{t, r}$, $l_{t, l}$ and $o_{t, o}$ show the unit costs, at time $t$, for the single purchases of raw materials, services, use of third-party assets, labor and other operating costs. All monetary costs in Equation (5) are in numbers $\geq 1$; the respective quantities purchased are $q_{t, m}, q_{t, s}, q_{t, r}, q_{t, 1}$ and $q_{t, o}$. Nonmonetary operating costs are as follows:

$$
D_{t}=\sum_{d=1}^{D} d_{\mathrm{t}, d} q_{t, d} \quad ; \quad A_{t}=\sum_{a=1}^{A} a_{t, a} q_{t, a}
$$

In Equation (6) $D_{t}$ is costs for amortization of tangible and intangible assets $\left(F A_{t}\right)$ and $A_{t}$ is impairments and provisions for risks. In Equation (6), $d_{t, d}$ and $a_{t, a}$ are unit costs, at time $t$, of individual amortization, depreciation and provision for risks. These costs are, respectively, in numbers $D \geq 1$ and $A \geq 1$. The respective amounts are $q_{t, d}$ and $q_{t, a}$. The balance of financial charges is given by:

$$
S F_{\mathrm{t}}=I_{t}^{a}-I_{t}^{p}+\left(I_{t}^{a c}-I_{t}^{p c}\right)
$$

In Equation (7) $I^{a}$ is interest income at time $t, I^{p}$ is interest payable at time $t$ and $\left(I^{a c}-I^{p c}\right)$ is the difference between the proceeds (positive) on exchange rates and charges (negative) on foreign exchange. The balance of extraordinary management $\left(S X_{t}\right)$, at time $\mathrm{t}$, is given by:

$$
S X_{t}=X_{t}^{a}-X_{t}^{p}
$$

In Equation (8), $X^{a}$ is extraordinary income, while $X^{p}$ is extraordinary expenses. The balance of revaluations and impairments of financial assets is given, at time $t$, by:

$$
S Z_{t}=Z_{t}^{a}-Z_{t}^{p}
$$

In Equation (9), $Z^{a}$ is revaluations and $Z^{p}$ is devaluations, i.e., increases and decreases in asset values. The change in value of these assets is respectively positive and negative income, from which, at time $t$, the following is derived:

$$
\begin{aligned}
& V P_{t}-\left(M_{t}+S_{t}+R_{t}+L_{t}+O_{t}\right)=E B I T D A_{t} ; \\
& E B I T D A_{t}-\left(D_{t}+A_{t}\right)=E B I T_{t} ; \\
& E B I T_{\mathrm{t}}+S F_{\mathrm{t}}+S X_{t}+S Z_{t}=\Pi_{t}^{a T}
\end{aligned}
$$

In Equation (10), Earnings before Interest, Tax, Depreciations and Amortizations (EBITDA) approximates the creation of liquidity into the cost, since no allowance is made for nonmonetary costs (D $+\mathrm{A})$, whereas no such feature is taken into account in 
relation to the value of production, considering monetary $\left(S_{t}\right)$ and nonmonetary values $\left(\Delta W C i_{t, t-1}\right)$. Earnings Before Interest and Tax (EBIT) is an intermediate profit margin expressing the current operating income and $\prod^{a T}$ is profit before tax, while the profit after tax $\left(\Pi^{p T}\right)$ is given by the following:

$$
\Pi_{t}^{a T}-T_{t}^{Y}=\Pi_{t}^{p T}
$$

In Equation (11), $\Pi^{p T}$ expresses remuneration, in period $t$, for equity capital contributed by the entrepreneur and $T^{Y}$ is total taxes on corporate income. At the end of the assessment of the sustainability of the business cycle, where EBITDA and EBIT margins are used, we must keep in mind that the profit margins do not consider the effect of revenues not collected from customers, purchases not paid to suppliers and changes in the value of the inventories. Only then, in a stable situation (no change in extensions granted and received from customers and suppliers, no variation in the average number of days inventory as kept in stock, no change in turnover, etc.), do we have equality (even with phase shift time) between income and financial margins. In any other situation, including simple changes in revenue, variations cause a difference between profit and financial margins, though only in the long run can we note this difference. Similarly, profit, calculated with the economic approach, may differ from the cash flow available for distribution to shareholders, in consideration of the phase shift between the economic cycle of value creation and the financial cycle of cash flow. It is therefore appropriate to consider the financial approach, identifying practical financial margins to compare with profit margins to verify the significance of any differences.

\section{Cash Flow Statement Analysis Approach}

In defining cash flow, which is relevant to management decisions, we changed our approach. An early definition considers cash flow to be the sum of an accounting result (profit or EBIT) plus depreciation and amortizations (Beaver, 1966). Other researchers (Gombola and Ketz, 1983) have begun to express cash flow by taking into account the absorption or generation of cash by the working capital cycle and this approach has been considered in several studies (Rayburn, 1986; Wilson, 1987; Finger, 1994; Lorek and Willinger, 1996; Sweeney, 2014). We can apply two methods to draft cash flow statements (Bradbury, 2011): The direct method (Dechow et al., 1998; Chittenden et al., 2000; Almeida et al., 2004; Farshadfar and Monem, 2013; Clacher et al., 2013) considers monetary revenues and costs as determinants of Cash Flow (CF), whereas the indirect method (Giacomino and Mielke, 1998; Carroll and Griffith, 2001; Bond et al., 2012) quantifies cash inflow generated by operations, deriving the analysis from an income margin (in this case, profit):

$$
\begin{aligned}
& \Pi_{t}^{p T}+\left(D_{t}+A_{t}\right)+S F_{t}=C F_{t} ; \\
& C F_{t} \pm \Delta N W C_{t}=O C F_{t} ; O C F_{t} \pm \Delta F A_{t}=U F C F_{t} ; \\
& U F C F_{t}-S F_{t}=F C F E_{t}
\end{aligned}
$$

In Equation (12), at a certain time $(t), \mathrm{CF}$ is cash flow, OCF is operating cash flow, UFCF is unlevered free cash flow and FCFE is free cash flow to equity. $U F C F_{t}$ is therefore the cash flow available, in a given time $(t)$, for the remuneration of financial debt and equity capital. This is done through the payment of interest on borrowings and through the distribution of profits to holders of equity. In view of the statutory form required by the legislature for the annual account, UFCF cannot be considered a cash flow margin available for reducing nondiscretionary financial debt. In the annual account, prepared in accordance with EU and Italian law, there is no information given to enable the division of bank debt maturing within twelve months as debt with a discretionary or nondiscretionary reduction. In a given period $(t)$, then, we suggest that UFCF be regarded as cash flow available for the reduction, discretionary and nondiscretionary, of financial debt. Consequently, FCFE is the cash available for distribution to shareholders. Given Equation (12), we can formulate this as $N F P_{t-1}$ $F C F E_{t}+d_{t}=N F P_{t}$, where $\mathrm{d}$ is dividend paid to shareholders in the year $t$. It is then clear that only if we consider financial margins as defined in the above model (CF, OCF, UFCF, FCFE) is it possible to discern the correct information about financial sustainability needed to pay financial debt costs, even repaying such costs during time NFP. Cash flow statement margins are even applied to calculate interest coverage margins (ICRs) particularly in capital intensive firms (Bonazzi and Iotti, 2014b). Again, only if it is verified that $F C F E>0$ is it possible to pay a dividend to shareholders, even if the maximum payout ratio is defined as the ratio between FCFE and $\Pi^{p T}$. For example, if the ratio between FCFE and $\Pi^{p T}$ is $\alpha$, a firm could pay only a part $\left(\alpha \Pi^{p T}\right)$ to shareholders as dividends. If UFCF is $<0$, the firm would not be able to pay the cost of debt (SF) even if economic margins (EBITA, EBIT and $\Pi^{p T}$ ) were positive. If the ratio between UFCF and SF is $\beta$, the firm can pay only a part ( $\beta \mathrm{SF}$ ) to banks as a cost of debt. We must remember that only UFC $>$ SF ensures firms' capacity to repay the cost of any debt.

\section{Results}

\section{Data Collection and Research Plan}

The analysis was conducted on a sample of 40 companies operating in the aquaculture sector in Italy. The sample firms are active corporations in FriuliVenezia Giulia, Veneto, Emilia-Romagna and Marche, on the west cost of the Adriatic Sea. Data were randomly 
drawn from annual accounts in the "computerized analysis of Italian firms" AIDA database. With a base year of 2008, the extraction dates cover a five-year period from 2009 to 2013. We considered a total of 200 firm-year data with no missing data in the database. The data analysis was performed using the SPSS statistical package, issue 19. Our random extraction of the sample firms from the database takes into account these parameters: (1) The extracted firms are limited companies as defined in the Italian Civil Code. Cooperative firms were not included. (2) The extracted firms are classified as aquaculture firms in accordance with the classification guidelines of the National Institute of Statistics of Italy (ISTAT), that is, ATECO Code A.03.2. This article develops our analysis as follows: (1) We reclassify the annual accounts of the firms, applying descriptive statistics to the balance sheet, income statement and cash flow statement. (2) We test whether there are statistically significant correlations in the values of economic margins (EBITA, EBIT, $\Pi^{p T}$ ) and financial margins (CF, OCF, UFCF, FCFE). (3) We test whether there are statistically significant differences between economic margins (EBITA, EBIT, $\Pi^{p T}$ ) and financial margins (CF, OCF, UFCF, FCFE). (4) We test two multiple regression models to explain FCFE values, first applying an economic approach and second a financial approach.

\section{Annual Account Analysis}

The analysis of the sample firms first considers the annual account data in Table 1; these data express the high level of capital intensity required for the aquaculture activities of the firms in the sample, given the value of production (TA/VP median value is $1.16 \%$ ). Sector firms are capital intensive, considering fixed assets and the working capital cycle.

The data of the sample show a positive skewness and negative curtosis for balance sheet values, with mean values higher than median. The Kolmogorov-Smirnov D statistic on normality of distribution shows that all balance sheet values do not follow normal distributions. Mean values demonstrate the importance of investment in fixed assets (43.67\% of TA) and inventories of working capital $(31.39 \%$ of TA). Aquaculture firms, in fact, need investment in land, buildings and machinery to store breeding fish. FA investments have an effect on increasing the source of capital needed to finance longterm investment, to be covered by $\mathrm{ET}$ or $\mathrm{DF}^{>12 \mathrm{M}}$. $\mathrm{WCi}^{\mathrm{a}}$ investments are the largest part of the investment and are particularly due by fish farming period, which is frequently eighteen to twenty months, determining an increase in working capital needed. To cover a $\mathrm{WCi}^{\mathrm{a}}$ investment, it is not suitable to use a short-term financial debt $\left(\mathrm{DF}^{<12 \mathrm{M}}\right)$ because the scheduled repayment time of $\mathrm{DF}^{<12 \mathrm{M}}$ in days is frequently shorter than the average $\mathrm{WCi}^{\mathrm{a}}$ cycle, expressed by $\mathrm{WCi}^{\mathrm{a}}$ days (I_DAYS), which can be calculated as $\mathrm{WCi}^{\mathrm{a}} \times 365$ : VP. If I DAYS $>365$, the firm needs to cover the $\mathrm{WCi}^{\mathrm{a}}$ investment by applying a long-term source of capital $\left(\mathrm{ET}\right.$ or $\left.\mathrm{DF}^{>12 \mathrm{M}}\right)$. Trade receivables are also a major factor in asset investment (15.94\% of TA); the high capital absorption due to $\mathrm{WCar}^{\mathrm{a}}$ investments is determined by large retail chains, whose bargaining power causes an increase in average days of credit payments (trade receivables). To cover a WCar $^{\mathrm{a}}$ investment, it is then suitable to use short-term financial debt $\left(\mathrm{DF}^{<12 \mathrm{M}}\right)$ or accounts payable to suppliers $\left(\mathrm{WCap}^{\mathrm{a}}\right)$, because the scheduled repayment time of $\mathrm{DF}^{<12 \mathrm{M}}$ or $\mathrm{WCap}^{\mathrm{a}}$ in days is frequently as long as the average $\mathrm{WCi}^{\mathrm{a}}$ cycle, expressed by $\mathrm{WCar}^{\mathrm{a}}$ days (AR_DAYS), which can be calculated as $\mathrm{WCar}^{\mathrm{a}} \times 365$ : $\mathrm{VP}$, expressing $\mathrm{WCap}^{\mathrm{s}}$ days (AP_DAYS) as $\mathrm{WCap}^{\mathrm{s}} \times$ 365: $(\mathrm{R}+\mathrm{S})$. If AP_DAYS $>$ AR_DAYS, the firm does not need DF to cover WCap ${ }^{\mathrm{a}}$.

In the sample, I_DAYS is 143.29 days, AR_DAYS is 72.75 and AP DAYS is 145.51, expressing that the financial operating cycle (I_DAYS + AR_DAYSAP_DAYS) has a length of 70.53 days, to be covered by DF or ET sources of capital. It is interesting to note that AP_DAYS $>$ AR_DAYS, expressing the bargaining power of considered aquaculture firms over their suppliers during payment terms. To cover their financial needs, the firms in the sample use financial debts as their main source of capital, given the fact that $\mathrm{DF}^{\mathrm{M}<12}+$ $\mathrm{DF}^{\mathrm{M}>12}$ is $60.19 \%$ of the TA, with a prevalence of loans maturing within twelve months $(38.59 \%$ of the TA) compared to loans maturing over twelve months $(21.60 \%)$. DF increases financial dependence through the credit system, thus increasing borrowing costs. Equity capital (ET) is in fact the third source of capital $\left(13.49 \%\right.$ of the TA). Stable sources of capital $\left(\mathrm{DF}^{\mathrm{M}>12}+\right.$ ET) are $35.08 \%$ of the TA, not ensuring the coverage of FA investments $(43.67 \%$ of TA). A part of the FA investment is then financed with short-term loans, expressing a typical amount of financial risk. It may therefore be appropriate for companies in the sector to continue to finance $\mathrm{WCi}^{\mathrm{a}}$ with credit lines in the medium term to align the timing of repayment with the proceeds arising from the potential breeding cycle of the fish. In this context, an important role can be played by loan consortia, which, by collateral signature in favor of lenders who finance the enterprise, can facilitate access to credit for companies through financing lines of medium terms (up to sixty months). These lines of credit are rarely given to firms because of the crisis in the financial market, the absence of collateral and high pricing levels that do not allow companies to access credit sustainably. If we express Net Invested Capital (NIC) as the sum of FA and NWC, we can express that FA is $60.62 \%$ of the TA and NWC is $39.38 \%$ of the TA. 
Table 1. Balance sheet data of the sample firms (200 firm-year) - reclassification of the balance sheet with financial approach

\begin{tabular}{|c|c|c|c|c|c|c|c|}
\hline Value & Mean $(€)$ & Mean $(\%$ TA $)$ & Median $(€)$ & Median (\% TA) & Stand. Dev. & Skewness & Curtosis \\
\hline$\overline{\text { FA }}$ & 1634973 & $43.67 \%$ & 1107660 & $38.70 \%$ & 372239 & 1.25 & $(0.64)$ \\
\hline $\mathrm{WCi}^{\mathrm{a}}$ & 1175258 & $31.39 \%$ & 986928 & $34.48 \%$ & 122034 & 1.12 & $(0.23)$ \\
\hline $\mathrm{WCar}^{\mathrm{a}}$ & 596714 & $15.94 \%$ & 548862 & $19.18 \%$ & 9978 & 0.55 & $(0.25)$ \\
\hline $\mathrm{WCo}^{\mathrm{a}}$ & 275383 & $7.36 \%$ & 203590 & $7.11 \%$ & 46752 & 0.65 & $(0.36)$ \\
\hline $\mathrm{WC}^{\mathrm{aT}}$ & 2047355 & $54.69 \%$ & 1739380 & $60.77 \%$ & 223260 & 2.38 & $(1.95)$ \\
\hline $\mathrm{L}$ & 61322 & $1.64 \%$ & 15226 & $0.53 \%$ & 33768 & 2.12 & (1.69) \\
\hline TA & 3743650 & $100.00 \%$ & 2862266 & $100.00 \%$ & 598512 & 1.91 & (1.67) \\
\hline ET & 504991 & $13.49 \%$ & 385998 & $13.49 \%$ & 93037 & 1.65 & (1.26) \\
\hline WCap $^{\mathrm{s}}$ & 690107 & $18.43 \%$ & 605484 & $21.15 \%$ & 65762 & 0.65 & $(0.35)$ \\
\hline $\mathrm{WCo}^{\mathrm{s}}$ & 295301 & $7.89 \%$ & 258226 & $9.02 \%$ & 32457 & 0.25 & $(0.06)$ \\
\hline $\mathrm{WC}^{\mathrm{sT}}$ & 985408 & $26.32 \%$ & 863710 & $30.18 \%$ & 103608 & 0.88 & $(0.69)$ \\
\hline $\mathrm{DF}^{\mathrm{M}<12}$ & 1444784 & $38.59 \%$ & 805665 & $28.15 \%$ & 467948 & 3.66 & $(2.97)$ \\
\hline $\mathrm{DF}^{\mathrm{M}>12}$ & 808467 & $21.60 \%$ & 806893 & $28.19 \%$ & 22872 & 0.05 & $(0.02)$ \\
\hline $\mathrm{DF}^{\mathrm{T}}$ & 2253251 & $60.19 \%$ & 1612558 & $56.34 \%$ & 473265 & 1.98 & $(1.65)$ \\
\hline DT & 3238659 & $86.51 \%$ & 2476268 & $86.51 \%$ & 552061 & 1.56 & $(1.20)$ \\
\hline TS & 3743650 & $100.00 \%$ & 2862266 & $100.00 \%$ & 627540 & 1.67 & (1.29) \\
\hline
\end{tabular}

Source: Our processing of directly collected data

Table 2. Income statement data of the sample firms (200 firm-year) - reclassification of the income statement with value added approach

\begin{tabular}{llllllll}
\hline Value & Mean $(€)$ & Mean $(\%$ VP) & Median $(€)$ & Median $(\%$ VP) & Stand. Dev. & Skewness & Curtosis \\
\hline VP & 2993724 & $100.00 \%$ & 2457003 & $100.00 \%$ & 379591 & 1.98 & $(0.26)$ \\
M & $(1211045)$ & $(40.45 \%)$ & $(1090225)$ & $(44.37 \%)$ & 86170 & $(1.65)$ & $(0.56)$ \\
S & $(520065)$ & $(17.37 \%)$ & $(496339)$ & $(20.20 \%)$ & 17586 & $(0.36)$ & $(0.24)$ \\
R & $(69790)$ & $(2.33 \%)$ & $(32678)$ & $(1.33 \%)$ & 26543 & $(0.76)$ & $0.68)$ \\
L & $(592327)$ & $(19.79 \%)$ & $(421322)$ & $(17.15 \%)$ & 120768 & $(0.02)$ & $(0.12)$ \\
O & $(204628)$ & $(6.84 \%)$ & $(124980)$ & $(5.09 \%)$ & 55392 & $(0.76)$ & $(0.26)$ \\
EBITDA & 395869 & $13.22 \%$ & 291459 & $11.86 \%$ & 74551 & 2.55 & $(0.68)$ \\
D & $(2554)$ & $(0.09 \%)$ & $(125)$ & $(0.01 \%)$ & 1692 & $(0.21)$ & $(0.48)$ \\
A & $(229176)$ & $(7.66 \%)$ & $(217006)$ & $(8.83 \%)$ & 7937 & $(0.98)$ & $(0.01)$ \\
EBIT & 164139 & $5.48 \%$ & 74328 & $3.03 \%$ & 63456 & 1.21 & $(0.37)$ \\
SF & $(107671)$ & $(3.60 \%)$ & $(64552)$ & $(2.63 \%)$ & 30164 & $(1.11)$ & $(0.07)$ \\
R & 1255 & $0.04 \%$ & 1988 & $0.08 \%$ & 61 & $(0.15)$ & $(0.19)$ \\
X & $(2900)$ & $(0.10 \%)$ & 1650 & $0.07 \%$ & 4151 & $(0.04)$ & $(0.05)$ \\
$\prod^{\mathrm{aT}}$ & 54823 & $1.83 \%$ & 13414 & $0.55 \%$ & 28891 & 1.26 & $(0.16)$ \\
T & $(25681)$ & $(0.86 \%)$ & $(6221)$ & $(0.25 \%)$ & 13316 & $(1.69)$ & $(0.98)$ \\
$\prod^{p T}$ & 29142 & $0.97 \%$ & 7193 & $0.29 \%$ & 14577 & 1.54 & $(0.95)$ \\
\hline
\end{tabular}

Source: Our processing of directly collected data

Table 3. Cash flow statement with indirect approach of the sample firms (200 firm-year)

\begin{tabular}{llllllll} 
Value & Mean $(€)$ & Mean $(\%$ FCFE) & Median $(€)$ & Median $(\%$ FCFE) & Stand. Dev. & Skewness & Curtosis \\
\hline$\Pi^{p T}$ & 29.142 & $936.44 \%$ & 7.193 & $(5.63 \%)$ & 14577 & 1.54 & $(0.95)$ \\
$+\mathrm{D}$ & 2.554 & $82.07 \%$ & 125 & $(0.10 \%)$ & 2165 & 0.07 & $(0.12)$ \\
$+\mathrm{A}$ & 229.176 & $7364.27 \%$ & 217.006 & $(169.74 \%)$ & 7648 & 0.15 & $(0.19)$ \\
$+\mathrm{SF}$ & 107.671 & $3459.87 \%$ & 64.552 & $(50.49 \%)$ & 30384 & 0.47 & $(0.40)$ \\
$\mathrm{CF}$ & 368.543 & $11842.64 \%$ & 288.876 & $(225.96 \%)$ & 56431 & 1.08 & $(0.96)$ \\
$-/+\Delta \mathrm{WCi}^{\mathrm{a}}$ & 110.210 & $3541.45 \%$ & 117.438 & $(91.86 \%)$ & 5434 & $(0.12)$ & 0.11 \\
$-/+\Delta \mathrm{WCar}^{\mathrm{a}}$ & 35.221 & $1131.78 \%$ & 45.996 & $(35.98 \%)$ & 8462 & $(0.07)$ & 0.32 \\
$-/+\Delta \mathrm{WCo}^{\mathrm{a}}$ & 12.110 & $389.14 \%$ & 5.608 & $(4.39 \%)$ & 4710 & 0.16 & 0.09 \\
$\Delta \mathrm{WC}^{\mathrm{aT}}$ & 157.541 & $5062.37 \%$ & 169.042 & $(1132.22 \%)$ & 8174 & $(0.08)$ & $(0.06)$ \\
$+/-\Delta \mathrm{WCap}^{\mathrm{s}}$ & $(15.665)$ & $(503.37 \%)$ & 5.867 & $(4.59 \%)$ & 15727 & $(0.15)$ & $(0.06)$ \\
$+/-\Delta \mathrm{WCo}^{\mathrm{s}}$ & $(22.114)$ & $(710.60 \%)$ & $(21.247)$ & $16.62 \%$ & 1343 & $(0.01)$ & $(0.02)$ \\
$\Delta \mathrm{WC} \mathrm{sT}^{\mathrm{T}}$ & $(37.779)$ & $(1213.98 \%)$ & $(15.380)$ & $12.03 \%$ & 15483 & $(0.21)$ & $(0.19)$ \\
$\Delta \mathrm{NWC}$ & $(119.762)$ & $3848.39 \%$ & $(153.662)$ & $120.19 \%$ & 23309 & $(0.37)$ & $(0.30)$ \\
OCF & 248.781 & $7994.25 \%$ & 135.214 & $(105.76 \%)$ & 79979 & 1.39 & 1.22 \\
$-/+\Delta \mathrm{FA}$ & $(137.998)$ & $4434.38 \%$ & $(198.507)$ & $155.27 \%$ & 42119 & $(0.53)$ & $0.91)$ \\
UFCF & 110.783 & $3559.87 \%$ & $(63.293)$ & $49.51 \%$ & 123124 & 2.17 & $(1.45$ \\
$-\mathrm{SF}$ & $(107.671)$ & $3459.87 \%$ & $(64.552)$ & $50.49 \%$ & 30027 & 0.39 & 0.31 \\
FCFE & 3.112 & $100.00 \%$ & $(127.845)$ & $100.00 \%$ & 92222 & 1.28 & 1.06 \\
\hline
\end{tabular}

Source: Our processing of directly collected data 
Thus, NWC $>0$ in 191 cases in the sample, expressing a high level of capital absorption in the NWC cycle, particularly because of the $\mathrm{WCi}^{\mathrm{a}}$ length in days (I_DAYS); the ET is $18.72 \%$ of the NIC, while the NFP is $81.28 \%$ of the NIC. The ratio between NFP and ET (net financial position equity ratio: NFP_E_R) is 4.34, expressing a high level of financial indebtedness, thus confirming the usefulness of assessing sustainability borrowing cost payment and financial debt repayment.

Further information on the typical characteristics of firms in the sector results from our analysis of economic data (Table 2). The average value of VP amounts to $€ 2,993,724$ and the major production factor is raw materials $(40.45 \%$ of VP). The cost of services is $17.37 \%$ of VP, while labor costs are the second highest at $19.79 \%$ of VP. EBITDA and EBIT are, respectively, 13.22 and $5.48 \%$ of VP. Financial charges (SF) absorb $3.60 \%$ of VP (i.e., $65.60 \%$ of EBIT and $27.20 \%$ of EBITDA) in mean values. Again, the median values of EBITDA and EBIT are lower than the mean values, as expressed by a comparison with those median values and EBITDA $>$ SF in 188 cases, while EBIT $>$ SF in only 131 cases. The median values of the income statement analysis show some cases of unsustainability in the operating cycle. The analysis of income statements again demonstrates that data have positive skewness and negative curtosis for the majority of values, with mean values higher than median. The Kolmogorov-Smirnov D statistic on normality of distribution shows that even all distributions of income statements do not follow a normal distribution.

Our analysis of cash flow statements (Table 3) highlights some typical management characteristics of firms in the aquaculture sector: (1) The dynamic of NWC investment absorbs a significant amount of liquidity generated by operations (CF) as expressed by OCF, particularly in $\mathrm{WCi}^{\mathrm{a}}$ investments due for breeding fish. (2) The dynamic of FA investments absorbs the largest part of the OCF, as expressed by UFCF values, making UFCF negative on median values. Given a mean OCF of $€ 248,781$, with a median OCF of $€ 135,214$, median net investments in FA are $€ 198,507$, resulting in a negative UFCF of $€ 63,293$ (mean: $€ 110,783$ ). SF absorbs further UFCF and determines a mean FCFE of $€ 3,112$ and a median negative FCFE value of $€ 127,845$. The analysis shows that the sample firms are not able to meet their financial commitments and repay the cost of debt; it is this median value of $\mathrm{FCFE}<0$ that demonstrates the inability of firms in the sample, on average, to then proceed to the distribution of profits and eventually repay their NFP, with the need to acquire additional debt (or improve equity capital) to financially support the cycle of business management. The analysis shows that sample firms are not able to cover the cost of debt without an increase in equity capital or an increase in the level of financial debt. This necessity of coverage expresses a financial situation where the median value is FCFE $<0$, implying an impossibility to distribute dividends, if any and reimburse the NFP. Given the difficulties in the current national financial situation and with access to additional bank credit, particularly for SMEs, our analysis of the differences between income and financial margins has a remarkably applicable interest and can provide entrepreneurs with necessary and suitable tools to prevent financial crises. In the current situation of difficulty in credit access, it could be useful to assess the sustainability of firms' cycles by comparing income margins and financial margins. EBITDA and EBIT, as economic margins, are frequently applied to assess sustainability of the business cycle and to approximate cash flow measurements, particularly as a debt-financing covenant (Moir and Sudarsanam, 2007). It is necessary to express that economic margins do not consider (1) the effect of sales to be collected from customers as $\Delta \mathrm{WCar}^{\mathrm{a}}$, (2) the purchases not paid to suppliers as $\Delta \mathrm{WCap}^{\mathrm{a}}$, or (3) the change in $\mathrm{WCi}^{\mathrm{a}}$ inventories. Only in a stable situation, in which there is no change in the extension granted and received by customers and suppliers (as $\triangle \mathrm{AR}$ DAYS $=0$ and $\triangle \mathrm{AP}$ DAYS $=0$ ), no variation in the average number of days of $\Delta \mathrm{WCap}^{\mathrm{a}}$ and no change in turnover (as $\Delta \mathrm{S}=0$ ) is there equality, even with lag time, between income and financial margins in the NWC cycle.

\section{Discussion}

\section{Economic and Financial Margins Analysis}

We aim to verify whether margins calculated with an economic approach (EBITDA, EBIT and profit) correlate to or differ significantly from margins calculated applying a financial approach (CF, OCF, UFCF and FCFE). The Kolmogorov-Smirnov D statistic (KSD) on normality of distribution shows that all considered margins, both economic and financial, do not follow normal distributions, so it was necessary to apply a nonparametric approach, such as Spearman's rho $(\rho)$ test, to test correlations between margins. The correlation calculated with the nonparametric approach (Table 4) shows several significant correlations between margins, with high significance $(1.00 \%)$. EBITDA is particularly correlated to other income margins and with $\mathrm{CF}$ and OCF, while it is not correlated to UFCF and FCFE. EBIT and $\Pi^{p T}$ are higher predictive values of financial margins, resulting in a correlation even to UFCF and FCFE. Even financial margins are correlated to one another, even if $\mathrm{CF}$ is slightly correlated to other financial margins and is not correlated to FCFE. OCF, UFCF and FCFE are highly correlated, even if OCF and UFCF are both correlated to FCFE with significance at the 0.10 level (two-tailed). 
Table 4. Correlation between income and financial margins-not parametric approach (Spearman's $\rho$ )

\begin{tabular}{|c|c|c|c|c|c|c|c|c|}
\hline & & EBITDA & EBIT & $\prod^{p T}$ & $\mathrm{CF}$ & $\mathrm{OCF}$ & UFCF & FCFE \\
\hline \multirow[t]{3}{*}{ EBITDA } & Corr. $\rho$ Spearman & 1 & $0.661 * * *$ & $0.520 * * *$ & $0.975 * * *$ & $0.612 * * *$ & 0.155 & 0.122 \\
\hline & Sig. (2-tailed) & & 0.000 & 0.000 & 0.000 & 0.000 & 0.151 & 0.212 \\
\hline & $\mathrm{N}$ & & 200 & 200 & 200 & 200 & 200 & 200 \\
\hline \multirow[t]{3}{*}{ EBIT } & Corr. $\rho$ Spearman & $0.661 * *$ & 1 & $0.234 * *$ & $0.731 * * *$ & $0.197 * *$ & $0.198 * *$ & $0.166^{*}$ \\
\hline & Sig. (2-tailed) & 0.000 & & 0.021 & 0.000 & 0.050 & 0.051 & 0.098 \\
\hline & $\mathrm{N}$ & 200 & & 200 & 200 & 200 & 200 & 200 \\
\hline \multirow[t]{3}{*}{$\prod^{p T}$} & Corr. $\rho$ Spearman & $0.520 * *$ & $0.234 * *$ & 1 & $0.190 *$ & $0.169 *$ & $0.166^{*}$ & $0.201 * *$ \\
\hline & Sig. (2-tailed) & 0.000 & 0.021 & & 0.056 & 0.098 & 0.099 & 0.045 \\
\hline & $\mathrm{N}$ & 200 & 200 & & 200 & 200 & 200 & 200 \\
\hline \multirow[t]{3}{*}{$\mathrm{CF}$} & Corr. $\rho$ Spearman & $0.975 * *$ & $0.731 * * *$ & $0.190 *$ & 1 & $0.170 *$ & $0.165 *$ & 0.101 \\
\hline & Sig. (2-tailed) & 0.000 & 0.000 & 0.056 & & 0.095 & 0.100 & 0.299 \\
\hline & $\mathrm{N}$ & 200 & 200 & 200 & & 200 & 200 & 200 \\
\hline \multirow[t]{3}{*}{$\mathrm{OCF}$} & Corr. $\rho$ Spearman & $0.612 * *$ & $0.197 * *$ & $0.169 *$ & $0.170 *$ & 1 & $0.330 * * *$ & $0.190^{*}$ \\
\hline & Sig. (2-tailed) & 0.000 & 0.050 & 0.098 & 0.095 & & 0.000 & 0.065 \\
\hline & $\mathrm{N}$ & 200 & 200 & 200 & 200 & & 200 & 200 \\
\hline \multirow[t]{3}{*}{ UFCF } & Corr. $\rho$ Spearman & 0.155 & $0.198 * *$ & $0.166^{*}$ & $0.165^{*}$ & $0.330 * * *$ & 1 & $0.185^{*}$ \\
\hline & Sig. (2-tailed) & 0.151 & 0.051 & 0.099 & 0.100 & 0.000 & & 0.067 \\
\hline & $\mathrm{N}$ & 200 & 200 & 200 & 200 & 200 & & 200 \\
\hline \multirow[t]{3}{*}{ FCFE } & Corr. $\rho$ Spearman & 0.122 & $0.166^{*}$ & $0.201 * *$ & 0.101 & $0.190 *$ & $0.185^{*}$ & 1 \\
\hline & Sig. (2-tailed) & 0.212 & 0.098 & 0.045 & 0.299 & 0.065 & 0.067 & \\
\hline & $\mathrm{N}$ & 200 & 200 & 200 & 200 & 200 & 200 & \\
\hline
\end{tabular}

***.The correlation is significant at the 0.01 level (two-tailed); **. The correlation is significant at the 0.05 level (two-tailed); *. The correlation is significant at the 0.10 level (two-tailed). Source: Our processing of directly collected data

Table 5. Comparison of economic and financial margins-not parametric approach for paired samples (T-Wilcoxon)

\begin{tabular}{|c|c|c|c|c|}
\hline Couple & $\begin{array}{l}\text { T-Wilcoxon } \\
\text { For paired sample stat. }\end{array}$ & $\begin{array}{l}\text { T-Wilcoxon } \\
\text { for paired sample stand. stat }\end{array}$ & Observ. & Sig. (2-tailed) \\
\hline Couple 1 EBITDA-CF & 12 & 0.845 & 200 & 0.391 \\
\hline Couple 2 EBITDA-OCF & 41 & 1.285 & 200 & 0.195 \\
\hline Couple 3 EBITDA-UFCF & 329 & -2.801 & 200 & $0.006 * * *$ \\
\hline Couple 4 EBITDA-FCFE & 412 & -7.101 & 200 & $0.000 * * *$ \\
\hline Couple 5 EBIT-CF & 23 & 0.905 & 200 & 0.372 \\
\hline Couple 6 EBIT-OCF & 102 & 1.102 & 200 & 0.312 \\
\hline Couple 7 EBIT-UFCF & 221 & -2.551 & 200 & $0.015 * *$ \\
\hline Couple 8 EBIT-FCFE & 330 & -3.159 & 200 & $0.005 * * *$ \\
\hline Couple $9 \prod^{\mathrm{pT}}-\mathrm{CF}$ & 127 & 1.491 & 200 & $0.092 *$ \\
\hline Couple $10 \prod^{\mathrm{pT}}-\mathrm{OCF}$ & 115 & 1.535 & 200 & $0.083 *$ \\
\hline Couple $11 \prod^{\mathrm{pT}}-\mathrm{UCFE}$ & 231 & -2.440 & 200 & $0.026^{* *}$ \\
\hline Couple $12 \prod^{\mathrm{pT}}$-FCFE & 301 & -3.992 & 200 & $0.000 * * *$ \\
\hline
\end{tabular}

***. The relation is significant at the 0.01 level (2-tailed); **. The relation is significant at the 0.05 level $(2$-tailed); $*$ The relation is significant at the 0.10 level (2-tailed); Source: Our processing of directly collected data

Our comparison between income (EBITDA, EBIT, $\Pi^{p T}$ ) and financial $(\mathrm{CF}, \mathrm{OCF}, \mathrm{UFCF}, \mathrm{FCFE})$ margins aims to evaluate the significance of the difference between mean values (Table 5). This analysis is useful both for theoretical purposes and to determine whether different margins could be applied as substitutes for one another. This information is also practically relevant for managers and banks to know whether they have applied the correct margins to assess the sustainability of firms' cycles. The Kolmogorov-Smirnov D statistic on normality of distribution showed that all distributions of the income and financial margins did not follow a normal distribution, so it was not considered necessary to apply a nonparametric approach such as the Wilcoxon T statistic (Wilcoxon Matched-Pairs Signed-
Ranks Test). The analysis is articulated considering twelve comparisons and shows that the comparison in pairs with a nonparametric approach highlights that it is possible to reject the null hypothesis of equality between means by applying a two-sided test with significance at $1.00 \%$ in four cases (couples 3, 4, 8 and 12), at $5.00 \%$ in two case (couples 7 and 11) and at $10.00 \%$ in two case (couples 9 and 10). Our analysis of the economic margins shows, for the sample firms, the sustainability assessment carried out through EBITDA and EBIT as the economic approach, even if these are frequently applied by firms and banks to evaluate the sustainability of firms' operating cycles. EBITDA, confirming correlation analysis, is suitable to approximate $\mathrm{CF}$ and OCF but is significantly different from UFCF and FCFE, 
as expressed by our analysis of couples 3 and 4 . At the same time, the EBIT margin statistically differs from UFCF and FCFE, as expressed by couples 7 and 8 . Again, $\Pi^{p T}$ is different from all financial margins, even if with a significance of $10.00 \%$ in the $\mathrm{CF}$ and $\mathrm{OCF}$ comparison. It is of note that EBITDA $>0$ in 191 cases and EBIT $>0$ in 171 cases. At the same time, $\Pi^{p T}>0$ in 127 cases, while $\mathrm{CF}>0$ in 179 cases, $\mathrm{OCF}>0$ in 146 cases, UFCF $>0$ in 78 cases and FCFE $>0$ in 51 cases. Given the differences that exist between economic and financial margins, it is essential that firms and credit institutions conduct an assessment of sustainability not only using income statements but also the cash flow statement, which, although optional, becomes a table of fundamental work to make available margins (even financial) properly expressive of the cash flow generated by analyzed firms. It is then possible to reduce, in this way, the risk of error in an assessment of the sustainability of a firm's business cycle and the instability of that enterprise, with implications being a reduction of social costs in terms of financial losses to creditors, loss of jobs, potential dispersion of intellectual capital and social costs related to the default of companies. The phase shift between the economic and financial cycles in aquaculture firms shows that the absorption of financial resources, due to the operating cycle of NWC and due to investments in FA, makes it so that financial margins cannot properly approximate economic margins in many cases.

\section{Multiple Regression Analysis}

Our analysis, applying regression, aims to quantify the causal relationship between a variable to be explained (the dependent variable) and one or more explanatory variables (independent variables), as exposed in the models. In the article, we would analyze whether there was a relation between FCFE, which expresses the amount of cash available for equity holders and some independent variables. We would apply an additive linear regression model, as follows, with two regression equations.

The first model (the economic model), expressed in Equation (13), considers $\mathrm{FCFE}_{\mathrm{t}}$ as an independent variable in a given time $(\mathrm{t})$; this information is important because aquaculture firms are often SMEs and are based on family labor. Availability of financial resources for distribution to shareholders is essential to ensure remuneration of shareholders with monetary distribution of dividends, as follows:

$$
\begin{aligned}
& F C F E_{t}=\alpha+\beta_{1} I \_D A Y S_{t}+\beta_{2} A R_{-} D A Y S_{t}+ \\
& +\beta_{3} A P_{-} D A Y S_{t}++\beta_{4} N F P_{-} E_{t}+\beta_{5} E B I T D A_{t}+ \\
& +\beta_{6} E B I T_{t}+\beta_{7} \Pi_{t}^{p T}+\beta_{8} E B I T D A_{t-1}+\beta_{9} E B I T_{t-1}+ \\
& +\beta_{10} \Pi^{p T}{ }_{t-1}+\varepsilon_{t}
\end{aligned}
$$

In the first model, as in Equation (13), the constant term is $\alpha$ and the common part concerns the length of the operating cycle, as established by the first three variables of the model (I_DAYS, AR_DAYS, AP_DAYS I $_{t}$. Considering debt level as the ratio between NFP and ET (NFP_ET ${ }_{t}$, we can thus approximate the Debt to Equity Ratio (DER) traditionally applied. The model considers core explanatory variables in EBITDA, that is, an explanatory variable considered in values for the years $t$ and $\mathrm{t}-1\left(\right.$ EBITDA $_{\mathrm{t}}$ and EBITDA $\left._{\mathrm{t}-1}\right)$. Even EBIT and $\prod^{p T}$ are considered explanatory variables in their values at years $t$ and $t-1$, having four other explanatory variables $\left(\mathrm{EBIT}_{\mathrm{t}}\right.$ and $\mathrm{EBIT}_{\mathrm{t}-1}, \Pi^{p T}{ }_{t}$ and $\left.\Pi^{p T}{ }_{t-1}\right)$. The model would verify whether it is possible to explain FCFE at a given time $(\mathrm{t})$ considering, as explanatory variables, three operating cycle variables (I_DAYS, AR_DAYS AP_DAYS $)_{t}$, one proxy of the NFP debt level $\left(\right.$ NFP_ET $\left.{ }_{t}\right)$ and three actual income margins (EBITDA, EBIT and $\left.\Pi^{p T}\right)$ and their respective values considered at time $\mathrm{t}-1 \quad\left(\mathrm{EBITDA}_{\mathrm{t}}, \mathrm{EBIT}_{\mathrm{t}}\right.$ and $\left.\Pi^{p T}{ }_{t}\right)$. The economic model, as expressed in Equation (13) and analyzed in Table 6, assumes a significant statistical capacity to explain $\mathrm{FCFE}_{\mathrm{t}}$ values. The $\mathrm{F}$ statistic for the considered model has high significance $(\mathrm{F}=0.011)$ and the majority of variables are significant, as well. Adjusted $R^{2}$ has the value 0.803 , expressing a fairly good capacity of the model to explain a great part of the variability of $\mathrm{FCFE}_{\mathrm{t}}$; the statistic DW is 2.332. Income margins EBIT $_{t}$ and EBIT $_{\mathrm{t}-1}$ are slightly significant (at the 0.10 level), while $\Pi^{p T}{ }_{t}$ and $\Pi^{p T}{ }_{t-1}$ are widely significant (at the 0.01 and 0.05 levels, respectively). EBITDA $_{t}$ and EBITDA $_{t-1}$ are not significant. In the model, the coefficients I_DAYS, AR_DAYS and NFP_E have positive effects and act negatively on FCFE, while AP_DAYS has a negative effect, all significant in the model. All explanatory variables are consistent with the economic theory. FCFE is widely influenced by income margins of the year in question, while margins of the previous year are less important as explanatory variables.

The second model, as in Equation (14), has commonalities with model of Equation (13): the variables regarding the length of the operating cycle $\left(I_{-D A Y S}, A_{t}\right.$ AR_DAYS, AP_DAYS ${ }_{t}$ ) and the ratio between NFP and ET (NFP_ET $\left.{ }_{t}\right)$. The model in Equation (14) considers $\mathrm{FCFE}_{\mathrm{t}}$ as an independent variable at a given time $(\mathrm{t})$, considering, as explanatory variables, the actual financial margins $\left(\mathrm{CF}_{\mathrm{t}}, \mathrm{OCF}_{\mathrm{t}}\right.$ and $\left.\mathrm{UFCF}_{\mathrm{t}}\right)$ and their respective values considered at time $\mathrm{t}-1\left(\mathrm{CF}_{\mathrm{t}-1}, \mathrm{OCF}_{\mathrm{t}-1}\right.$ and $\left.\mathrm{UFCF}_{\mathrm{t}-1}\right)$. We define Equation (14) as a financial model because it does not consider income margins (as would an economic model) but rather financial margins as explanatory variables: 
Table 6. Extract of the multiple regression model that shows the impact on FCFEt of economic independent variables (economic model, Equation (13))

\begin{tabular}{|c|c|c|c|c|c|}
\hline \multirow[b]{2}{*}{ Model } & \multicolumn{2}{|c|}{ Unstandardized coefficient } & \multicolumn{2}{|c|}{ Standardized coefficient } & \multirow[b]{2}{*}{ Sig. } \\
\hline & $\mathrm{B}$ & Std. Error & Beta & $\mathrm{T}$ & \\
\hline$\overline{(\alpha \text { Constant })}$ & -0.220 & 0.019 & - & 5.001 & $0.000 * * *$ \\
\hline $\mathrm{I}_{-} \mathrm{DAYS}_{\mathrm{t}}$ & 0.011 & 0.102 & $(0.122)$ & -2.243 & $0.024 * *$ \\
\hline$\overline{\mathrm{AR}} \mathrm{DAYS}_{\mathrm{t}}$ & 0.060 & 0.045 & $(0.096)$ & -1.973 & $0.051^{*}$ \\
\hline $\mathrm{AP}_{-}^{-} \mathrm{DAYS}_{\mathrm{t}}$ & 0.020 & 0.015 & 0.441 & 2.550 & $0.012 * *$ \\
\hline NFP_E $E_{t}$ & 0.036 & 0.112 & $(0.155)$ & 2.860 & $0.004 * *$ \\
\hline EBITDA $_{t}$ & 0.223 & 0.170 & 0.120 & 1.280 & 0.204 \\
\hline $\mathrm{EBIT}_{\mathrm{t}}$ & 0.144 & 0.162 & 0.336 & 1.955 & $0.055^{*}$ \\
\hline$\Pi_{t}^{p T}{ }_{t}$ & 0.155 & 0.212 & 0.331 & 2.579 & $0.009 * * *$ \\
\hline EBITDA $_{t-1}$ & 0.091 & 0.023 & 0.205 & 0.840 & 0.401 \\
\hline $\mathrm{EBIT}_{\mathrm{t}-1}$ & 0.332 & 0.221 & 0.327 & 1.712 & $0.091 *$ \\
\hline$\prod_{t-1}^{p T}$ & 0.265 & 0.098 & 0.078 & 2.201 & $0.027 * *$ \\
\hline
\end{tabular}

Economic model, Equation 13. Dependent variable: $\mathrm{FCEF}_{\mathrm{t}} ; * * *$. The relation is significant at the 0.01 level (2-tailed); **. The relation is significant at the 0.05 level (2-tailed); *. The relation is significant at the 0.10 level (2-tailed); Source: Our processing of directly collected data

Table 7. Extract of the multiple regression model that shows the impact on the $\mathrm{FCFE}_{\mathrm{t}}$ of economic independent variables (financial model, Equation (14))

\begin{tabular}{|c|c|c|c|c|c|}
\hline \multirow[b]{2}{*}{ Model } & \multicolumn{2}{|c|}{ Unstandardized coefficient } & \multicolumn{2}{|c|}{ Standardized coefficient } & \multirow[b]{2}{*}{ Sig. } \\
\hline & $\mathrm{B}$ & Std. Error & Beta & $\mathrm{T}$ & \\
\hline$\overline{(\alpha \text { Constant })}$ & -0.220 & 0.019 & - & 5.001 & $0.000 * * *$ \\
\hline $\mathrm{I}_{-} \mathrm{DAYS}_{\mathrm{t}}$ & 0.011 & 0.102 & $(0.122)$ & -2.243 & $0.024 * *$ \\
\hline$\overline{\mathrm{AR}} \_$DAYS $\mathrm{s}_{\mathrm{t}}$ & 0.060 & 0.045 & $(0.096)$ & -1.973 & $0.051 *$ \\
\hline $\mathrm{AP}_{-}^{-} \mathrm{DAYS}_{\mathrm{t}}$ & 0.020 & 0.015 & 0.441 & 2.550 & $0.012 * *$ \\
\hline NFP_E $E_{t}$ & 0.036 & 0.112 & $(0.155)$ & 2.860 & $0.004 * *$ \\
\hline $\mathrm{CF}_{\mathrm{t}}{ }^{-}$ & 0.124 & 0.385 & 1.080 & 1.280 & 0.201 \\
\hline $\mathrm{OCF}_{\mathrm{t}}$ & 1.001 & 0.191 & 0.455 & 2.578 & $0.009^{* * *}$ \\
\hline $\mathrm{UFCF}_{\mathrm{t}}$ & 0.992 & 0.221 & 0.401 & 2.585 & $0.008^{* * *}$ \\
\hline $\mathrm{CF}_{\mathrm{t}-1}$ & 0.082 & 0.289 & 0.105 & 0.890 & 0.361 \\
\hline $\mathrm{OCF}_{\mathrm{t}-1}$ & 0.802 & 0.106 & 0.552 & 1.670 & $0.095^{*}$ \\
\hline $\mathrm{UFCF}_{\mathrm{t}-1}$ & 0.668 & 0.442 & 0.138 & 2.001 & $0.044 * *$ \\
\hline
\end{tabular}

Economic model, Equation 14. Dependent variable: $\mathrm{FCEF}_{\mathrm{t}}$;***. The relation is significant at the 0.01 level (2-tailed); **. The relation is significant at the 0.05 level (2-tailed); *. The relation is significant at the 0.10 level (2-tailed); Source: Our processing of directly collected data

$$
\begin{aligned}
& F C F E_{t}=\alpha+\beta_{1} I_{-} D A Y S_{t}+\beta_{2} A R \_D A Y S_{\mathrm{t}}+ \\
& +\beta_{3} A P \_D A Y S_{\mathrm{t}}+\beta_{4} N F P_{-} E_{\mathrm{t}}+\beta_{5} C F_{t}+ \\
& +\beta_{6} O C F_{\mathrm{t}}+\beta_{7} U F C F_{\mathrm{t}}+\beta_{8} F C F E_{t}++\beta_{9} C F_{t}+ \\
& +\beta_{10} O C F_{\mathrm{t}}+\beta_{11} U F C F_{t}+\beta_{12} F C F E_{t}+\varepsilon_{t}
\end{aligned}
$$

The financial model analyzed in Table 7 assumes a high statistical capacity to explain $\mathrm{FCFE}_{\mathrm{t}}$ values. The $\mathrm{F}$ statistic for the considered model has high significance $(\mathrm{F}=0.000)$, while the adjusted $\mathrm{R}^{2}$ has the value 0.922 , expressing the capacity of the model to explain the variability of $\mathrm{FCFE}_{\mathrm{t}}$. The statistic DW is 2.105 and the majority of the variables are significant. The financial margins of the year, $\mathrm{OCF}_{\mathrm{t}}$ and $\mathrm{UFCF}_{\mathrm{t}}$, are highly significant (at the 0.001 level) and, at the same time, the financial margins of the previous year, $\mathrm{OCF}_{\mathrm{t}-1}$ and $\mathrm{UFCF}_{\mathrm{t}-1}$, are relatively significant (at the 0.10 and 0.05 levels, respectively). $\mathrm{CF}_{\mathrm{t}}$ and $\mathrm{CF}_{\mathrm{t}-1}$ are not significant.
As in the first model, the coefficients of I DAYS, AR_DAYS and NFP_E have negative effects on FCFE, while AP_DAYS has a positive effect. It is interesting to note that FCFE is highly influenced by the financial margins of the year, while the intermediate financial margins of the previous year are less important as explanatory variables. The model expresses an important result for the aquaculture sector, where FCFE is affected more by financial variables, particularly OCF and UFCF, while intermediate profit margins have a lower explanatory power.

\section{Conclusion}

The analysis conducted in Italy allow to qualify aquaculture firms as capital intensive. Indeed, investment in fixed assets and working capital are, in absolute value, higher than the value of production. Such 
absorption of capital is determined in particular by the fishes' breeding cycle, which spans over twelve months, as the average length of the inventories cycle.

Through the research, it emerged that the main source of capital to finance assets is financial debt, which exceeds the equity capital, expressing the financial dependence of aquaculture firms on banks. The sample data show that, in any case, the income margins of companies are positive, although with low capital turnover and profitability. The ability to repay the cost of debt is also low with income margins. The sample analysis confirmed that aquaculture firms must strengthen their capital structures by increasing equity capital and paying a considerable reduction of the working capital cycle. Likewise, it is necessary to improve profitability through actions of differentiation of production and enhancement of the finished product.

Firms in the sample rarely acted on these strategies. The main difficulties for firms were related to the financial cycle. In fact, the sample firms have financial margins (OFC, UFCF and FCFE, in particular) worse than their economic margins (EBITDA, EBIT and $\Pi^{p T}$ ), with various corporate crises highlighted by negative financial margins. The analysis thus shows that income margins are, on average, higher than financial margins and that the presence of positive economic margins does not guarantee the financial sustainability of firms. In fact, the analysis highlights that income margins are statistically different and higher, than financial margins, as shown by the results of the application of the $T$ Wilcoxon statistic for paired samples.

In particular, financial margins (UFCF and FCFE, particularly), although related, are statistically different from economic margins (EBITDA, EBIT and $\Pi^{p T}$ ). The generation of FCFE is the critical element of aquaculture firms and in fact, $\Pi^{p T}>0$ in 127 cases, while $\mathrm{FCFE}>0$ in only 51 cases. To estimate FCFE, two regression models were applied, first an economic model, then a financial model. The analysis shows that the financial model has greater power to explain FCFE creation and this model is particularly affected by the variables inherent in working capital (I_DAYS and AP_DAYS), indebtedness (NFP_E) and cash flow (OCF and UFCF).

The research has therefore highlighted not only the difference between income and financial margins but also that profit margins are less powerful in explaining FCFE, while financial margins could be applied properly. Aquaculture firms have to prefer to directly apply financial margins (especially OCF, UFCF and FCFE) rather than approximate them with economic margins (EBITDA, EBIT and $\Pi^{p T}$ ).

However, our research has some limitations. Firstly, the sample analyzed was related to a small number of firms (forty) over a five-year timespan. It could be useful to extend the analysis over a larger sample over a tenyear span. The analysis could even be repeated over the next few years, also considering the effect of the current economic crisis on the annual accounts of companies. The research will be further improved by including cooperatives in the analysis. This type of company is indeed frequent in the aquaculture sector, but the typicality of their annual accounts makes it difficult to compare cooperatives and limited companies.

Also, future research could include in the analysis partnerships and sole proprietorships. These types of legal businesses, in fact, are not obliged to file annual accounts to the Corporate Registry and therefore no related data are available publicly. It may also be useful to undertake a comparative analysis with other countries of the Mediterranean Basin to see whether the strengths and weaknesses of aquaculture firms in Italy also characterize firms in other Mediterranean countries.

\section{Acknowledgement}

The researchers would thank analisiaziendale it for IT assistance, particularly in the database management.

\section{Funding Information}

The authors did not receive any private or public funding to develop the research.

\section{Author's Contributions}

This study is a result of the full collaboration of all the authors.

Mattia Iotti: Wrote paragraphs Cash flow statement analysis approach, Economic and financial margins analysis, Multiple regression analysis and Conclusion.

Giuseppe Bonazzi: Wrote paragraphs Introduction, Balance sheet analysis approach, Income statement analysis approach, Data collection and research plan and Annual account analysis.

\section{Ethics}

The authors have not conflicts of interest in the development and publication of current research.

\section{References}

Almeida, H., M. Campello and M. Weisbach, 2004. The cash flow sensitivity of cash. J. Finance, 59: 1777-1804.

DOI: $10.1111 /$ j.1540-6261.2004.00679.x

Arcelus, F.J. and G. Srinivasan, 1993. Integrating working capital decisions. Engineering Economist, 39: 1-15. DOI: 10.1080/00137919308903110

Bagella, M., L. Becchetti and A. Caggese, 2001. Financial constraints on investments: A three-pillar approach. Res. Econmoics, 55: 219-254. 
Baños-Caballero, S., P.J. García-Teruel and P. MartínezSolano, 2013. The speed of adjustment in working capital requirement. Eur. J. Finance, 19: 978-992. DOI: $10.1080 / 1351847 X .2012 .691889$

Baños-Caballero, S., P.J. García-Teruel and P. MartínezSolano, 2014. Working capital management, corporate performance and financial constraints. Source Document J. Bus. Res., 67: 332-338.

Beaver, W.H., 1966. Financial ratios as predictors of failure. Empirical research in accounting: Selected studies. Supplement J. Account Res.

Bedecarratz, P.C., D.A. López, B.A. López and O.A. Mora, 2011. Economic feasibility of aquaculture of the giant barnacle Austromegabalanus psittacus in southern Chile. J. Shellfish Res., 30: 147-157. DOI: $10.2983 / 035.030 .0122$

Bhattacharya, P. and K.N. Ninan, 2011. Social costbenefit analysis of intensive versus traditional shrimp farming: A case study from India. Nat. Res. Forum, 35: 321-333.

DOI: $10.1111 /$ j.1477-8947.2011.01385.x

Bonazzi, G. and M. Iotti, 2014a. Agricultural cooperative firms: Budgetary adjustments and analysis of credit access applying scoring systems. Am. J. Applied Sci., 11: 1181-1192. DOI: 10.3844/ajassp.2014.1181.1192

Bonazzi, G. and M. Iotti, 2014b. Interest Coverage Ratios (ICRs) and financial sustainability: Application to firms with bovine dairy livestock. Am. J. Agric. Biol. Sci., 9: 482-489.

DOI: 10.3844 /ajabssp.2014.482.489

Bonazzi, G., M. Iotti and F. Paduano, 2012. Valutazioni di convenienza e di sostenibilità per le imprese del comparto del Prosciutto di Parma Dop: Un'analisi attraverso l'applicazione di indici economici e finanziari. Rivista di Economia Agraria, 38: 61-98.

Bond, D., M. Bugeja and R. Czernkowski, 2012. Did australian firms choose to switch to reporting operating cash flows using the indirect method? Aus. Accounting Rev., 22: 18-24. DOI: $10.1111 / \mathrm{j} .1835-2561.2011 .00156 . \mathrm{x}$

Boschi, M., A. Girardi and M. Ventura, 2014. Partial credit guarantees and SMEs financing. J. Financ. Stability, 15: 182-194. DOI: $10.1016 /$ j.jfs.2014.09.007

Bozoglu, M. and V. Ceyhan, 2009. Cost and profitability analysis for trout and sea bass production in the Black Sea, Turkey. J. Anim. Vet. Adv., 8: 217-222.

Bradbury, M., 2011. Direct or indirect cash flow statements? Aus. Accounting Rev., 21: 124-130. DOI: $10.1111 / \mathrm{j} .1835-2561.2011 .00130 . \mathrm{x}$

Caggese, A. and V. Cunat, 2014. Financing constraints, firm dynamics, export decisions and aggregate productivity. Rev. Economic Dynamics, 16: 177-193.

Caggese, A., 2007. Testing financing constraints on firm investment using variable capital. J. Financ. Economics, 86: 683-723.

DOI: $10.1016 /$ j.jfineco.2006.11.005
Carluccia, D., G. Nocella, B. De Devitiis, R. Viscecchia and F. Bimbo et al., 2015. Consumer purchasing behaviour towards fish and seafood products. Patterns and insights from a sample of international studies. Appetite, 84: 212-227.

DOI: $10.1016 /$ j.appet.2014.10.008

Carroll, C. and J.M. Griffith, 2001. Free cash flow, leverage and investment opportunities. Q. J. Bus. Econ., 40: 141-153.

Chittenden, F., P. Poutziouris and N. Michaelas, 2000. Financial Management and Working Capital Practices in UK SMES. 1st Edn., Manchester Business School, United Kingdom.

Christensen, V., J. Steenbeek and P. Failler, 2011. A combined ecosystem and value chain modeling approach for evaluating societal cost and benefit of fishing. Ecol. Model., 222: 857-864.

DOI: 10.1016/j.ecolmodel.2010.09.030

Clacher, I., A.D. de Ricquebourg and A. Hodgson, 2013. The value relevance of direct cash flows under international financial reporting standards. Abacus, 49: 367-395. DOI: $10.1111 /$ abac. 12010

Cleary, S., 1999. The Relationship between firm investment and financial status. J. Finance, 54: 673-692. DOI: 10.1111/0022-1082.00121

Copeland, K.A., W.O. Watanabe and C.F. Dumas, 2005. Economic evaluation of a small-scale recirculating system for ongrowing of captive wild black sea bass Centropristis striata in North Carolina. J. World Aquacult. Soc., 36: 489-497. DOI: $10.1111 /$ j.1749-7345.2005.tb00396.x

Darun, M.R., J. Roudaki and J. Radford, 2015. Forces shaping working capital management practices: A preliminary study. Int. Bus. Management, 9: 301-318.

De Blasi, G., A. De Boni, R. Roma and G. Trevisan, 2012. The social capital for adriatic small pelagic fish value-enhancing: A network analysis. New Medit, 11: 27-32.

De Ionno, P.N., G.L. Wines, P.L. Jones and R.O. Collins, 2006. A bioeconomic evaluation of a commercial scale recirculating finfish growout system-an Australian perspective. Aquaculture, 259: 315-327. DOI: 10.1016/j.aquaculture.2006.05.047

De Miguel, A. and J. Pindado, 2001. Determinants of capital structure: New evidence from Spanish panel data. J. Corporate Finance, 7: 77-99. DOI: 10.1016/S0929-1199(00)00020-1

Dechow, P.M. and I. Dichev, 2002. The quality of accruals and earnings: The role of accrual estimation errors. Account. Rev., 3: 35-59. DOI: $10.2308 /$ accr.2002.77.s-1.35

Dechow, P.M., 1994. Accounting earnings and cash flows as measures of firm performance: The role of accounting accruals, J. Accoun. Econ., 18: 3-42. DOI: 10.1016/0165-4101(94)90016-7 
Dechow, P.M., S.P. Kothari and R.L. Watts, 1998. The relation between earnings and cash flows. J. Accoun. Econ.. 25: 133-168. DOI: $10.1016 / \mathrm{S} 0165-4101(98) 00020-2$

Dechow, P.M., A.P. Hutton, J.H. Kim and R.G. Sloan, 2012. Detecting earnings management: A new approach. J. Accoun. Res., 50: 275-334. DOI: $10.1111 /$ j.1475-679X.2012.00449.x

Di Trapani, A.M., F. Sgroi, R. Testa and S. Tudisca, 2014. Economic comparison between offshore and inshore aquaculture production systems of European sea bass in Italy. Aquaculture, 434: 334-339.

DOI: $10.1016 / j$.aquaculture.2014.09.001

Dunn, P. and L. Cheatham, 1993. Fundamentals of small business financial management for start-up, survival, growth and changing economic circumstances. Managerial Finance., 19: 1-13. DOI: 10.1108/eb013737

El-Gayar, F.O., 2003. Aquaculture in Egypt and issues for sustainable development. Aquacult. Econ. Manag., 7: 137-154.

DOI: $10.1080 / 13657300309380336$

El-Sayed, A.F.M., M.V. Dickson and G.O. El-Naggar, 2014. Value chain analysis of the aquaculture feed sector in Egypt. Aquaculture, 437: 92-101. DOI: 10.1016/j.aquaculture.2014.11.033

Emdad Haque, C., C. Julián Idrobo, F. Berkes and D. Giesbrecht, 2015. Small-scale fishers' adaptations to change: The role of formal and informal credit in Paraty, Brazil. Marine Policy, 51: 401-407. DOI: 10.1016/j.marpol.2014.10.002

FAO, 2012a. The state of world fisheries and aquaculture. FAO Fisheries and Aquaculture, Roma.

FAO, 2012b. Global aquaculture production statistics. Food and Agriculture Organization of the United Nations.

FAO, 2013a. Fishery and aquaculture statistics. Rome.

FAO, 2013b. FAOSTAT.

Farshadfar, S. and R. Monem, 2013. Further evidence on the usefulness of direct method cash flow components for forecasting future cash flows. Int. J. Accoun., 48: 111-133.

DOI: $10.1016 /$ j.intacc.2012.12.001

Fazzari, S. and B. Petersen, 1993. Working capital and fixed investment: New evidence on financing constraints. RAND J. Econ., 24: 328-342.

Ferreira, J.G., C. Saurel and J.M. Ferreira, 2012. Cultivation of gilthead bream in monoculture and integrated multi-trophic aquaculture. Analysis of production and environmental effects by means of the FARM model. Aquaculture, 358-359: 23-34. DOI: $10.1016 /$ j.aquaculture.2012.06.015

Finger, C.A., 1994. The ability of earnings to predict future earnings and cash flow. J. Account. Res., 32: 210-223.
Giacomino, D.E. and D.E. Mielke, 1988. Using the statements of cash flows to analyze corporate performance. Manage. Accoun., 69: 54-57.

Glancey, K., 1998. Determinants of growth and profitability in small entrepreneurial firms. Int. J. Enterpreneurial Behav. Res., 4: 18-27. DOI: $10.1108 / 13552559810203948$

Gombola, M.J. and E.J. Ketz, 1983. A note on cash flow and classification patterns of financial ratios. Account. Rev., 58: 105-114.

Gordini, N., 2014. A genetic algorithm approach for SMEs bankruptcy prediction: Empirical evidence from Italy. Expert Syst. Applic., 41: 6433-6445. DOI: 10.1016/j.eswa.2014.04.026

Grablowsky, B.J., 1976. Mismanagement of accounts receivable by small business. J. Small Bus., 14: 23-28.

Gray, S., A. Mirkovic and V. Ragunathan, 2006. The determinants of credit ratings: Australian evidence. Aus. J. Manage., 31: 333-354. DOI: $10.1177 / 031289620603100208$

Greenberg, R.R., G.L. Johnson and K. Ramesh, 1986. Earnings versus cash flow as a predictor of future cash flow measures. J. Accoun., 4: 266-277. DOI: $10.1177 / 0148558 X 8600100402$

Guillen, J. and A. Motova, 2013. The economic performance of the EU Aquaculture Sector (STECF 13-29). JRC of European Commission.

Hadelan, L., V. Par, M. Njavro and M. Lovrinov, 2012. Real option approach to economic analysis of European sea bass (Dicetrarchus labrax) farming in Croatia. Agric. Conspec. Sci., 77: 161-165.

Hill, M.D., G.W. Kelly and M.J. Highfield, 2010. Net operating working capital behavior: A first look. Financ. Manage., 39: 783-805. DOI: $10.1111 /$ j.1755-053X.2010.01092.x

Holmer, M., 2010. Environmental issues of fish farming in offshore waters: perspectives, concerns and research needs. Aquacult. Environ. Interact., 1: 57-70. DOI: $10.3354 /$ aei00007

Howorth, C. and P. Westhead, 2003. The focus of working capital management in UK small firms. Manag. Account. Res., 14: 94-111. DOI: $10.1016 / \mathrm{S} 1044-5005(03) 00022-2$

Iotti, M. and G. Bonazzi, 2014a. The application of Life Cycle Cost (LCC) approach to quality food production: A comparative analysis in the Parma PDO ham sector. Am. J. Applied Sci., 11: 1492-1506. DOI: 10.3844/ajassp.2014.1492.1506

Iotti, M. and G. Bonazzi, 2014b. Tomato processing firms' management: A comparative application of economic and financial analyses. Am. J. Applied Sci., 11: 1135-1151. DOI: 10.3844 /ajassp.2014.1135.1151

Iotti, M. and G. Bonazzi, 2014c. Life cycle flow analysis: Methodological improvement and application to the Parma PDO ham sector. Quality Access Success, 15: 98-103. 
Kaiser, M.J., Y. Yu and B. Snyder, 2010. Economic feasibility of using offshore oil and gas structures in the Gulf of Mexico for platform-based aquaculture. Mar. Policy, 34: 699-707.

DOI: 10.1016/j.marpol.2010.01.002

Kieschnick, R., M. LaPlante and R. Mousawwi, 2008. Working capital management, corporate governance and firm value. University of North Texas University Press, Austin.

Kieschnick, R., M. Laplante and R. Moussawi, 2013. Working capital management and shareholders' wealth. Rev. Finance, 17: 1827-1852.

DOI: $10.1093 /$ rof/rfs043

Kim, D. and D. Lipton, 2011. A comparison of the economic performance of offshore and inshore aquaculture production systems in Korea. Aquac. Econ. Manag., 15: 103-117. DOI: $10.1080 / 13657305.2010 .549165$

Kim, D.H., D. Lipton and J.Y. Choi, 2012. Analyzing the economic performance of the red sea bream Pagrus major offshore aquaculture production system in Korea. Fish. Sci., 78: 1337-1342. DOI: $10.1007 / \mathrm{s} 12562-012-0540-2$

Kroes, J.R. and A.S. Manikas, 2014. Cash flow management and manufacturing firm financial performance: A longitudinal perspective. Int. J. Production Econ., 148: 37-50. DOI: 10.1016/j.ijpe.2013.11.008

Kwon, Y.K., 1989. Accrual versus cash-basis accounting methods: An agency-theoretic comparison. J. Accoun. Public Policy, 8: 267-281. DOI: $10.1016 / 0278-4254(89) 90015-X$

Lanfranchi, M., C. Giannetto and A. Puglisi, 2014. A cost-benefits analysis for risk management in a biological farm. Applied Math. Sci., 8: 775-787.

Lorek, K.S. and G. Willinger, 1996. A multivariate timeseries prediction model for cash-flow data. Account. Rev., 71: 81-102.

Love, I., L.A. Preve and V. Sarria-Allende, 2007. Trade credit and bank credit: Evidence from recent financial crises. J. Financ. Econ., 83: 453-469. DOI: $10.1016 /$ j.jfineco.2005.11.002

Macfadyen, G., A.M. Nasr-Alla, D. Al-Kenawy, M. Fathi and H. Hebicha et al., 2012. Value-chain analysis-an assessment methodology to estimate Egyptian aquaculture sector performance. Aquaculture, 362-363: 18-27.

Modina, M. and F. Pietrovito, 2014. A default prediction model for Italian SMEs: The relevance of the capital structure. Applied Financ. Econ., 24: 1537-1554. DOI: $10.1080 / 09603107.2014 .927566$

Moir, L. and S. Sudarsanam, 2007. Determinants of financial covenants and pricing of debt in private debt contracts: The UK evidence. Accounting Bus. Res., 37: 151-166.

DOI: $10.1080 / 00014788.2007 .9730066$
Molina, C.A. and L.A. Preve, 2009. Trade receivables policy of distressed firms and its effect on the costs of financial distress. Financ. Manage., 38: 663-686. DOI: 10.1111/j.1755-053X.2009.01051.X

Molinos-Senante, M., F. Hernández-Sancho and R. SalaGarrido, 2010. Economic feasibility study for wastewater treatment: A cost-benefit analysis. Sci. Total Environ., 408: 4396-4402. DOI: $10.1016 /$ j.scitotenv.2010.07.014

Nasir, N.M. and S.N. Abdullah, 2004. Information provided by accrual and cash flow measures in determining firms' performance: Malaysian evidence. Am. J. Applied Sci., 1: 64-70. DOI: $10.3844 /$ ajassp.2004.64.70

Naziri, D., 2011. Financial services for SME aquaculture producers Egypt case study. Natural Resources Institute.

Orpurt, S.F. and Y. Zang, 2009. Do direct cash flow disclosures help predict future operating cash flows and earnings? Accoun. Rev., 84: 893-935. DOI: 10.2308 /accr.2009.84.3.893

Padachi, K., 2006. Trends in working capital management and its impact on firms' performance: An analysis of mauritian small manufacturing firms. Int. Rev. Bus. Res. Pap., 2: 45-56.

Peel, M.J. and N. Wilson, 1996. Working capital and financial management practices in the small firm sector. Int. Small Bus. J., 14: 52-68. DOI: $10.1177 / 0266242696142004$

Rayburn, J., 1986. The association of operating cash flow and accruals with security returns. J. Accoun. Res., 24: 112-133. DOI: 10.2307/2490732

Russel, P.B., 2009. The cash flow implications of managing working capital and capital investment. J. Bus. Econ. Stud., 15: 98-108.

Saccurato, F., 1994. The Study of Working Capital. Business Credit., 96: 36-47.

Santulli, A. and A. Modica, 2009. Aquaculture in Sicily: The state of the art. Ital. J. Anim. Sci., 8: 829-837. DOI: 10.4081/ijas.2009.s2.829

Sgroi, F., A.M. Di Trapani, R. Testa and S. Tudisca, 2014. Strategy to increase the farm competitiveness. Am. J. Agric. Biol. Sci., 9: 394-400.

Sgroi, F., M. Candela, A.M. Di Trapani, M. Foderà and R. Squatrito et al., 2015. Economic and financial comparison between organic and conventional farming in sicilian lemon orchards. Sustainability, 7: 947-961. DOI: 10.3390/su7010947

Shamshak, G.L., 2011. Economic evaluation of capturebased bluefin tuna aquaculture on the US east coast. Mar. Resour. Econ., 26: 309-328. DOI: $10.5950 / 0738-1360-26.4 .309$

Shi, H., W. Zheng, X. Zhang, M. Zhu and D. Ding, 2013. Ecological-economic assessment of monoculture and integrated multi-trophic aquaculture in Sanggou Bay of China. Aquaculture, 410-411: 172-178. 
Strano, A., A.I. De Luca, C. Marcianò and G. Gulisano, 2014. The agronomic utilisation of Olive Mill Wastewater (OMW): Technical and economic tradeoffs in olive growing in Calabria (South Italy). Quality-Access to Success, 15: 86-91.

Sweeney, R.J., 2014. Equivalent valuations in cash flow and accounting models. Rev. Quantitative Finance Accoun., 42: 29-49. DOI: $10.1007 / \mathrm{s} 11156-012-0332-\mathrm{x}$

Taylor, D., 2011. Optimizing Working Capital. 1st Edn., Business Credit, VI.

Tudisca, S., A.M. Di Trapani, F. Sgroi and R. Testa, 2013. The cost advantage of Sicilian wine farms. Am. J. Applied Sci., 10: 1529-1536. DOI: 10.3844 /ajassp.2013.1529.1536

Tudisca, S., A.M. Di Trapani, F. Sgroi and R. Testa, 2014a. Economic evaluation of PDO introduction in Sicilian orange farms. Quality Access Success, 14: 99-103.
Tudisca, S., A.M. Di Trapani, F. Sgroi and R. Testa, 2014b. Organic farming and economic sustainability: The case of Sicilian durum wheat. Quality Access Success, 15: 93-96.

Ukaegbu, B., 2014. The significance of working capital management in determining firm profitability: Evidence from developing economies in Africa. Res. Int. Bus. Finance, 31: 1-16. DOI: 10.1016/j.ribaf.2013.11.005

Vilela, M.C., K.D. de Araújo, L. de Souza Machado and M.R.R. Machado, 2013. Feasibility analysis of financial and economic project in excavated aquaculture tanks. Custos Agronegocio, 9: 154-173.

Wilson, G.P., 1987. The incremental information content of accrual and funds components of earnings after controlling for earnings. Account. Rev., 62: 293-322. 